\title{
Nutritive composition and essential elements evaluation of some leafy vegetables grown in Gubi Fadama Land, Bauchi, Nigeria
}

\author{
Yunus, M.M. ${ }^{{ }^{*}}$, Abdullahi, L. ${ }^{1}$ \\ ${ }^{1 * 1}$ Department of Chemistry, Yobe State University KM 7, Gujba Road, P.M.B.1144 Damaturu, Nigeria

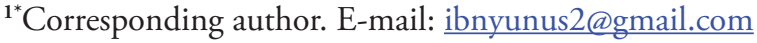

Received: 12 August 2020 / Accepted: 15 November 2020 / Published online: 29th January 2021

\begin{abstract}
Proximate analysis and some essential elements content of four leafy vegetable species namely: Brassica oleracea, Spinacia oleracea, Lactuca sativa and Hibiscus sabdariffa leaves were determined using standard analytical methods. These vegetables were widely consumed as food across Northeastern Nigeria. It is imperative to ascertain their nutritive values as they now form part of human diet for people in the area. Some of the results of the mean values ranged such as ash $(2.33 \pm 0.75-6.03 \pm 1.23 \%)$, moisture $(23.60 \pm 0.76-30.90 \pm 0.34 \%)$, lipid $(0.45 \pm 0.00$ $4.73 \pm 0.21 \%)$ and protein $(2.62 \pm 0.10-3.38 \pm 0.013 \%)$. The mineral elements values ranged like potassium $(145.47 \pm 4.50-935.60 \pm 2.45 \mathrm{mg} / 100 \mathrm{~g})$, sodium $(74.97 \pm$ $0.20-389.85 \pm 0.02 \mathrm{mg} / 100 \mathrm{~g})$, calcium $(9.87 \pm 0.13-14.55$ $\pm 0.94 \mathrm{mg} / 100 \mathrm{~g})$ iron $(1.30 \pm 0.05-2.17 \pm 0.15 \mathrm{mg} / 100 \mathrm{~g})$, magnesium $\quad(0.030 \pm 0.00-0.047 \pm 0.01 \mathrm{mg} / 100 \mathrm{~g}$ and manganese $(0.004 \pm 0.00-0.015 \pm 0.00 \mathrm{mg} / 100 \mathrm{~g})$. The work suggested that the leaves investigated contained appreciable amounts of nutrients. Their consumption could augment the unavailable or rarely available nutrients in human body. Comparatively, they are good sources of $\mathrm{K}, \mathrm{Na}, \mathrm{Ca}$ and $\mathrm{Fe}$, as well as fiber, moisture, and carbohydrates on the dietary menu recommendation. All the studied leaves have low lipid and protein content as well as copper, magnesium, and manganese.
\end{abstract}

Key words: Essential elements, Brassica oleracea, Lactuca sativa, nutrients content, crude lipid.

\section{INTRODUCTION}

A balanced diet notion has shifted recently to accommodate less red meat and more fruits and vegetables which are advised for consumption (Aletor et al., 2002; Singh et al., 2001). A balanced diet food shall comprise of the following food classes namely; vitamins, proteins, carbohydrates, fats, mineral elements and water. Each food class listed has its diet formation contribution (Saidu \& Jideobi, 2009). Vegetables are plant species which include young succulent leaves, fruits, seed, roots and stems. Usually they are low in sugar, fat and salt which make them good food source (Kavitha \& Saradha, 2013). Leafy vegetables consist of cellulose, hemi-cellulose and pectin materials which are responsible for their texture and firmness. They are widely used for culinary purposes and are rich in vitamins (especially vitamin C) and chemical elements that are essential for the maintenance of health, prevention and treatment of various diseases (Sobukola et al., 2007; Mohammed \& Sharif, 2011). Preparation of vegetable meals shall be done in a manner that will retain the entire vitamins present, because vitamins are often lost through oxidation and leaching during processing (Saidu \& Jideobi, 2009). Although vegetables contained low amounts of proteins yet they are very important in maintaining good health (Brain \& Allan, 1986; Otles \& Ozgoz, 2014). Vitamins are part of a balanced diet which are derived from fresh vegetables with emphasis on vitamins $\mathrm{B}_{6}, \mathrm{C}$, A and $\mathrm{E}$, which are important for healthy living and body metabolic processes (FAO/WHO, 2004). Vitamin $\mathrm{C}$ is an important antioxidant derived from leafy vegetables which is known to enhance the immune system of human body (Levine, 1995). 
Chemical elements or minerals which are inorganic in nature cannot be produced by human/animals, since they are essential to nutrition requirements; they must be provided through the intake of food and water. They are usually needed in small amounts depending on the nutrient concerned. Diet balance requires chemical elements that support the biochemical reactions of metabolism with the desired elemental components. Some of the mineral elements of biological importance include $\mathrm{Fe}, \mathrm{Na}, \mathrm{K}, \mathrm{Ca}$, $\mathrm{Mg}, \mathrm{Cu}, \mathrm{P}$ and $\mathrm{Zn}$. These chemical elements also stabilize the $\mathrm{pH}$ of acidic materials synthesized in the course of food digestion (Radwan \& Salama, 2006; Angela et al., 2010). The vegetables selected in this study are widely consumed as food across Northeastern Nigeria and some other parts of the country. It is imperative therefore to ascertain the nutritive values of these vegetables as they now form part of human diet for people in that area. This paper reports an assessment of the nutritive values and the mineral elements content of the leaves of Brassica oleracea, Spinacia oleracea, Lactuca sativa and Hibiscus sabdariffa grown in Gubi fadama farms, Bauchi with a view to ascertain dietary levels in the vegetables consumed.

\section{MATERIALS AND METHODS}

\section{Sample collection and treatment}

Four different leafy vegetables were collected from farmer's field in three different locations of Gubi Fadama area for the analysis. The vegetables include Brassica oleracea (cabbage), Hibiscus sabdariffa (Roselle), Lactuca sativa (lettuce) and Spinacia oleracea (spinach). The fresh leaves sample were removed from the stalk; some portion of the leaves were used for moisture determination. The other portion was cleaned with distilled water to remove soil particles and other unwanted material, then subjected to air-drying at ambient temperature for five days on an open surface laboratory bench to avoid bacterial or fungal growth. The leaves were dried again in an oven operated at $105^{\circ} \mathrm{C}$ for 8 hours. The dried leaves samples were converted to fine powder using mortar and pestle for the analysis. Nutritive analysis comprising (ash, moisture contents, crude fiber, lipid, protein and carbohydrate) were determined using standard laboratory analytical methods described by AOAC (2012), that is; ash and moisture contents (incineration using muffle at $550^{\circ} \mathrm{C}$ and Dry oven method at $105^{\circ} \mathrm{C}$ respectively), crude protein (Kjeldehl method), crude lipid ( Soxlet extraction method), crude fiber (acid refluxing and muffle furnace incineration method), while carbohydrate content was determined by subtracting the total crude lipid, crude fiber, crude protein and ash from the total dry matter.

\section{Materials required}

Micro pipette $1 \mathrm{~cm}^{3}$ (Joan lab), Kjeldehl Unit (ZDON-
11, Gallenkomp UK), Colorimeter (5marts, Chofo-USA), Oven (Mino 150/300, Gren lab.), Microwave Digester (Master-40, Sineo), Soxlet extractor (24/29, Gallenkomp), Furnace (6000, Galen product), Single channel flame photometer (PFP-7, Jenway) and Atomic absorption spectrophotometer (210-VGP, Bulk Scientific USA). The reagents used include; asw $(2 \%) \mathrm{H}_{3} \mathrm{BO}_{3}(\mathrm{v} / \mathrm{v}),(5 \%)$ $\mathrm{HNO}_{3}(\mathrm{v} / \mathrm{v}),(1.25 \%) \mathrm{H}_{2} \mathrm{SO}_{4}(\mathrm{v} / \mathrm{v}),(3 \%) \mathrm{HCl}(\mathrm{v} / \mathrm{v}),(15 \%)$ $\mathrm{NaOH}(\mathrm{w} / \mathrm{v}),(1.5 \%) \mathrm{H}_{2} \mathrm{O}_{2}(\mathrm{v} / \mathrm{v})$ and petroleum ether.

\section{Digestion of samples}

The nutritive content of the leaves for each element was determined by wet digestion method as adopted by (Anjorin et al., 2010). The digestion was carried out as; $3 \mathrm{~g}$ of the powdered sample was put in a beaker, $30 \mathrm{~cm}^{3}$ concentrated nitric acid was added then digested using heating mantle at $90^{\circ} \mathrm{C}$ for 1 hour. Blank solution was prepared using same procedure. The contents of the beaker were cooled, filtered and transferred to volumetric flask, then the volume was raised to $100 \mathrm{~cm}^{3}$ by means of distilled water. The concentrations of heavy trace elements such as iron $(\mathrm{Fe})$, copper $(\mathrm{Cu})$, manganese $(\mathrm{Mn})$, calcium (Ca) and magnesium $(\mathrm{Mg})$ in the vegetable samples were determined using Atomic Absorption Spectrophotometer equipped with an air acetylene burner. Blanks and standard solutions for device calibration were prepared and used. The samples were aspirated and absorbance was displayed and recorded. The absorbance was converted to concentration using Beer- Lambert's Law. Flame photometer was used to determine the amounts of sodium $(\mathrm{Na})$ and potassium $(\mathrm{K})$ in the samples. The machine was calibrated using blank (distilled water) and standards $(0.5 \mathrm{~g}$ of $\mathrm{NaCl}$ and $0.5 \mathrm{~g}$ $\mathrm{KCl})$. The samples solution was aspirated and results were recorded.

\section{RESULTS AND DISCUSSION}

Tables 1 and 2 present the nutritive composition and mineral element levels for the leafy vegetables samples investigated. Nutritional analysis of all the leafy vegetables was carried out on dry basis except for moisture content. The result obtained indicates that ash values range between 6.03 to $2.33 \%$ with Spinacia oleracea having the highest while Lactuca sativa having the least value. Brassica oleracea (5.93\%) showed the next high value amongst the four vegetables investigated. The presence of ash could be explained due to higher content of fiber and chemical elements in Spinacia oleracea and Brassica oleracea than the other vegetables. This suggest that Spinacia oleracea and Brassica oleracea contained valuable amounts of mineral elements when consumed. The percentage ash content values obtained are higher than what was reported by (Saidu and Jideobi, 2009) for water leaf and bitter leaf $1.6 \%, 2.5 \%$ respectively. However, Amaranthus viridis and 
Alternanthera sessilis leaves were reported to have less ash values of $1.85 \%$ and $1.5 \%$ respectively compared to the present result (Gotruvalli et al., 2016). This suggest that the vegetables studied in this work showed high chemical elements content than what was reported for $A$. viridis and A. sessilis vegetables.

Results of moisture content for the investigated leaves are presented in Table 1 . It shows that $B$. oleracea has the highest moisture content (30.90\%), followed by L. sativa (29.75\%) with Hibiscus sabdariffa (23.60\%) showing the lowest value. Possession of high moisture could depend on large number of cell saps each vegetable leaf possess. A slight difference in values was noticeable amongst the vegetables yet the values recorded for all the four leaves samples studied have a close range. This might be due to similar growing conditions, nature of soil (Fadama land), and climate under which the vegetables were planted. The values recorded are far below those reported by Iheanacho and Ubebani (2009) for Cardiospermum halicacabum, Mollugo pentaphylla and Pisonia grandis whose values were $77.80 \%, 73.99 \%$ and $71.43 \%$ respectively. Values recorded for lipid analysis shows that $S$. oleracea had the highest lipid value (4.73\%), while L. sativa had the lowest $(0.45 \%)$. B. oleracea and H. sabdariffa each has $3.38 \%$ and $2.18 \%$ respectively. This study indicates that the vegetables investigated have moderately low amount of lipid which agrees with literature report.

Fiber content is higher in Brassica oleracea (7.43\%) when compared to the values of S. oleracea (6.58\%) and $L$. sativa $(7.40 \%)$, while $H$. sabdariffa $(5.86 \%)$ had the lowest. The values obtained from these findings are comparatively higher than what was reported by Nisha et al. (2012) and Gotruvalli et al. (2016) for the leaves of Amaranthus viridis and Alternanthera sessilis with values of $1.93 \%$ and $3.40 \%$ respectively. The results from this study fall below those reported for Vernonia amygdalina (bitter leaf), Talinum fruticosum (water leaf) and Telfairia occadentalis (fluted pumpkin) whose values are $11.5 \%$, $11.51 \%$ and 13.23 respectively (Akinwunmi \& Omotayo, 2016; Kavitha \& Saradha, 2013; Tayyeb et al., 2017). Hanif et al. (2006) asserted that the presence of high fiber contributes significantly to nutritive value as fiber lowers body cholesterol level and consequently decreases the risk of cardiovascular diseases.

Protein content for leafy vegetables studied ranged from $3.38 \%$ to $2.62 \%$ with $B$. oleracea having the highest value while $H$. sabdariffa had the lowest value. Likewise, L. sativa and S. oleracea followed closely to B. oleracea with $3.37 \%$ and $3.00 \%$ respectively. These results are comparable to the leaves of Alternanthera sessilis (4.5\%) and Amaranthus viridis $(2.11 \%)$ as reported by Gotruvalli et al. (2016) and Nisha et al. (2012). Results presented in Table 1, fall below what was reported for the leaves of Moringa oleifera and Momordica balsamina whose values are $20.72 \%$ and $11.29 \%$ respectively (Asaolu et al., 2012). Proteins are important nutrients needed for growth and maintenance by human body (Lal, 2008; Garrett \& Grisham, 2005). Krause and Mahan (1984) and Lal (2008) reported protein deficiency could lead to mental retardation. This finding indicates that vegetables studied can make good sources of protein when consumed.

The available $\mathrm{CHO}$ content ranged from $7.45 \%$ to $26.63 \%$ with $H$. sabdariffa showing the lowest while $B$. oleracea having the highest in the leafy vegetables investigated. Carbohydrate is needed in the body for energy production. Leafy vegetables are often consumed with other carbohydrate rich foods, consequently; they may not be significant source of carbohydrates (Sizer \& Whitney, 2003; Arasaretnam et al., 2018). This result is comparable with that of Akinwunmi and Omotayo (2016) who reported $4.71 \%, 23.62 \%$ and $26.77 \%$ carbohydrate values for Talinum fruticosum, Solanum macrocarpon and Enidoscolus aconitifolius leafy vegetables respectively. The result suggests that $B$. oleracea and $S$. oleracea are good sources of carbohydrates hence, that make them a very good source of energy for the body. This ability makes the investigated vegetables valuable in a meal.

\section{Mineral composition}

The chemical elements profile of the investigated leaves is depicted in Table 2 . The highly soluble mineral elements of sodium, potassium, calcium, magnesium and iron play significant role in the regulation of body $\mathrm{pH}$ (Vasudevan \& Sreekumari, 2009). Sodium content ranged from 74.97 to $389.85 \mathrm{mg} / 100 \mathrm{~g}$ with $B$. oleracea having the highest while $H$. sabdariffa showing the lowest amongst the four studied vegetables. The result of sodium is comparatively high to those reported for Cardiospermum halicacabum, Delonix elata, Mollugo pentaphylla and Pisonia grandis whose values stand at 190.2, 186.7, 116.4 and 182.9 $\mathrm{mg} / 100 \mathrm{~g}$ respectively. Potassium values ranged between 145.47 to $935.60 \mathrm{mg} / 100 \mathrm{~g}$ with $L$. sativa having the highest while $S$. oleracea had the lowest value. These results are higher than potassium concentrations (94.5, $127.3 \mathrm{mg} / 100 \mathrm{~g}$ ) as reported by Arasaretnam et al. (2018) for Mollugo pentaphylla and Premna latifolia respectively. The study showed that $L$ sativa and B. oleracea are very good sources of $\mathrm{K}^{+}$and $\mathrm{Na}^{+}$which are major cations of extra and intracellular fluids needed to maintain normal body fluid and electrolyte balance (Angela et al., 2010). Calcium concentrations in the samples analyzed ranged from 9.87 to $14.55 \mathrm{mg} / 100 \mathrm{~g}$ with $L$. sativa and S. oleracea having the lowest and highest values respectively. The analysis shows that magnesium concentration ranged from 
0.030 to $0.047 \mathrm{mg} / 100 \mathrm{~g}$, with the two species maintaining status quo for magnesium amongst the studied vegetables. However, it was reported from literature that $\mathrm{K}, \mathrm{Na}, \mathrm{Ca}$ and $\mathrm{Mg}$ were most abundantly available in leafy vegetables meal. Calcium and magnesium are among the most important trace elements involved in the building of rigid structures to support the body. However, magnesium was found in lesser quantity amongst the vegetables tested, but calcium occurred in moderate amounts in all the investigated vegetables. Osborne and Vogt (1978) reported that magnesium and calcium when found in appreciable quantities are essential for the development of strong bones and teeth. Human body needs calcium to keep bones and teeth strong and ensure proper muscle functions (Kavitha \& Saradha, 2013). Lack of Ca and Mg in a diet may be responsible for weak and stunted growth as well as poor bone development (Effiong \& Udo, 2010). The results of the two elements appears as follows when arrange in descending order of the studied vegetables: $L$. sativa $<B$. oleracea $<H$. sabdariffa $<S$. oleracea .

The concentration of iron ranged from 1.30 to 2.17 $\mathrm{mg} / 100 \mathrm{~g}$ in the tested leafy samples with L. sativa having the lowest while $S$. oleracea had the highest amount of iron content as depicted in Table 2. Presence of iron in a diet is essential for infants, pregnant and nursing mothers. Iron is required in the production of red blood cell and ensures its function as an oxygen carrier (D'Mello, 2003; Latunde $\&$ Dada, 2009). On the other hand iron is a constituent of many proteins in the body which plays a vital role in numerous metabolic processes where iron reacts with haemoglobin to form oxyhaemoglobin that is required for red blood cells formation (UNICEF, 1998). Being an abundant chemical element in most soils and an important source of nourishment for all organisms, iron deficiency is reported to impede metabolism (Mahwash et al., 2011). All the species tested have values which are lower in iron content than those reported for Solanum macrocarpon $(40.31 \mathrm{mg} / 100 \mathrm{~g})$, Corchorus olitorius $(27.25 \mathrm{mg} / 100 \mathrm{~g})$ and Ocimum gratissimum $(2.55 \mathrm{mg} / 100 \mathrm{~g}$ ) (Akinwunmi \& Omotayo, 2016). Iron concentration appears relatively low comparable to the results reported above, yet appreciable amounts of iron needed were present in the leafy vegetables studied.

From the results shown concentrations of copper in the leaves are very close in values yet they vary significantly as shown in Table 2 . The values ranged between 0.148 to $0.240 \mathrm{mg} / 100 \mathrm{~g}$ with $L$. sativa having the lowest value while $S$. oleracea exhibiting the highest copper concentration. Copper is a trace element that occur in most soils which is required in lesser amounts in plants and animals for proper metabolism but becomes toxic when taken in larger quantities (Monaci et al., 2000). Values obtained for the leaves samples studied were comparably below those reported for Helianthus annus $(1.98 \mathrm{mg} / 100 \mathrm{~g})$, Lactuca sativa $(2.3 \mathrm{mg} / 100 \mathrm{~g})$ and Brassica oleracea $(2.0 \mathrm{mg} / 100 \mathrm{~g})$, (Uwah et al., 2011).

Table 1: Proximate composition of the investigated leaves (\%).

\begin{tabular}{lllllll}
\hline Plant name & Ash (\%) & Moisture (\%) & Crude lipid (\%) & Fiber (\%) & Protein (\%) & CHO (\%) \\
\hline B. oleracea & $5.93 \pm 1.27$ & $30.90 \pm 0.34$ & $3.38 \pm 0.23$ & $7.43 \pm 0.04$ & $3.38 \pm 0.013$ & $26.63 \pm 0.11$ \\
H. sabdariffa & $4.39 \pm 1.06$ & $23.60 \pm 0.76$ & $2.18 \pm 0.76$ & $5.86 \pm 0.76$ & $2.62 \pm 0.10$ & $7.45 \pm 0.23$ \\
L. sativa & $2.33 \pm 0.75$ & $29.75 \pm 0.21$ & $0.45 \pm 0.00$ & $7.40 \pm 0.04$ & $3.37 \pm 0.13$ & $13.75 \pm 0.22$ \\
S. oleracea & $6.03 \pm 1.23$ & $27.20 \pm 0.23$ & $4.73 \pm 0.21$ & $6.58 \pm 0.03$ & $3.00 \pm 0.12$ & $18.01 \pm 0.09$
\end{tabular}

Values are mean \pm SD triplicate analysis of samples on dry weight basis.

Table 2. Elemental composition of the investigated leaves (mg/100g).

\begin{tabular}{lccccccc} 
Plant name & Na & K & Ca & Mg & Cu & Mn & Fe \\
\hline B. oleracea & $389.85 \pm 0.02$ & $623.75 \pm 1.63$ & $11.47 \pm 0.15$ & $0.035 \pm 0.01$ & $0.172 \pm 0.01$ & $0.013 \pm 0.00$ & $1.51 \pm 0.06$ \\
H. sabdariffa & $74.97 \pm 0.20$ & $189.89 \pm 0.20$ & $13.34 \pm 0.17$ & $0.040 \pm 0.01$ & $0.200 \pm 0.01$ & $0.015 \pm 0.00$ & $1.75 \pm 0.07$ \\
L. sativa & $311.90 \pm 0.82$ & $935.60 \pm 2.45$ & $9.87 \pm 0.13$ & $0.030 \pm 0.00$ & $0.148 \pm 0.01$ & $0.011 \pm 0.00$ & $1.30 \pm 0.05$ \\
S. oleracea & $126.38 \pm 2.23$ & $145.47 \pm 4.50$ & $14.55 \pm 0.94$ & $0.047 \pm 0.01$ & $0.240 \pm 0.02$ & $0.004 \pm 0.00$ & $2.17 \pm 0.15$
\end{tabular}

Values are mean \pm SD triplicate analysis of samples on dry weight basis. 
Manganese concentration in the analyzed leaves samples fall between 0.004 to $0.015 \mathrm{mg} / 100 \mathrm{~g}$ where $S$. oleracea and $H$. sabdariffa showed the lowest and highest values respectively. The amount of $\mathrm{Mn}$ obtained in this study is the lowest for all the mineral elements tested for all the leafy vegetables investigated. The low values recorded for $\mathrm{Mn}$ and other elements tested for, can be attributed to difference in climatic (rainfall and temperature) as well as genetic (soil and plant type) factors that could influence the nutrients/chemical elements composition (Pennmington, 1995). The data obtained suggest that, the vegetables studied can be valuable and can contribute immensely to the diet of the people of Gubi area and Bauchi metropolitan as a whole.

\section{CONCLUSION}

From the study conducted, it is shown that the leafy vegetables investigated are nutritious with low moisture contents in relation to values reported by Saidu and Jideobi (2009) for Talinum triangulare (91.61\%) and Telfairia occidentalis $(98.5 \%)$, ash and protein contents compared to results reported by Onwordi et al. (2009) for Corchorus olitorius (21.4\%) and Argenta C. (32.40\%) and Amarathus cruentus (11.20\%) and Corchorus olitorius $(12.70 \%)$ respectively. Lipid content is low compared to values reported by Akinwunmi and Omotayo (2016) for Talinum fructicusum (30.59\%) and Enidoscolus aconitifolius (15.33\%) leafy vegetables. Likewise, moderate amounts of fiber and carbohydrate values were recorded. Vegetables are known to provide moderate amounts of nutrients required for normal body functions and maintenance. Results for mineral elements indicated presence of high contents of sodium and potassium in relation to values reported by Arasaretnam et al. (2018) in Premna latifolia $(130.60 \mathrm{mg} / 100 \mathrm{~g})$ and Mollugo pentaphylla $(116.40 \mathrm{mg} / 100 \mathrm{~g})$ for sodium as well as Pisonia grandis $(100.60 \mathrm{mg} / 100 \mathrm{~g})$ and Mollugo pentaphylla $(94.50 \mathrm{mg} / 100 \mathrm{~g})$ for potassium respectively, with moderate levels of calcium and iron. It was observed that nutrients composition in all the selected vegetables were different. The work revealed that leaves investigated contained considerable amounts of nutrients that can be utilized at affordable cost. Consequently, their consumption can augment the unavailable or rarely available nutrients. Comparatively, the leaves are rich in $\mathrm{K}, \mathrm{Na}, \mathrm{Ca}$ and $\mathrm{Fe}$, as well as fiber and carbohydrates on the dietary menu recommendation.

\section{REFERENCES}

Akinwunmi, O. A. 1., \& Omotayo, F. O. (2016). Proximate analysis and nutritive values of ten common vegetables in South-West Nigeria. Communications in Applied Sciences, 4(2), 79-91.
Aletor., Oshodi, A. A., \& Ipinmoroti, K., (2002). Chemical composition of common leafy vegetables and functional properties of their leaf protein concentrates. Food Chemistry, 78(2), 63-68.

Angela, C., Rodica, C., Andrea, M. Z., Elena, T., \& Camelia, G. (2010). Chemical composition of common leafy vegetables. University studies, Series of Life Sciences, 20(2), 45-48.

Anjorin, T. S., Ikokoh, P., \& Okolona, S. (2010). Mineral composition of Moringa oleifera leaves, pods, and seeds from two regions in Abuja, Nigeria. Inter. Jour. of Agriculture and Biology, 12(2), 431-434.

A.O.A.C. (2012). Williams S. (edition). Official methods of analysis ( $\left.16^{\text {th }} \mathrm{ed}\right)$. Association of official analytical chemists, Washington, DC.

Arasaretnam, S., Kiruthika A., \& Mahendran, T. (2018). Nutritional and mineral composition of selected green leafy vegetables. Ceylon Journal of Science, 47(1), 3541.

Asaolu, S. S., Adefemi, O. S., Oyakilome, I. G., Ajibulu, K. E., \& Asaolu, M. F. (2012). Proximate and mineral composition of Nigerian leafy vegetables. Journal of Food Research, 1(3), 214-218.

Brain, A. F., \& Allan, G. C. (1986). Food science. A chemical approach $15^{\text {th }}$ edition. Edward Arnold publishers Ltd London. Pp 210-211.

D'Mello, J. P. F. (2003). Contamination and toxins. CABI Publishing, Wallingford, Oxon, UK, Cambridge, M. A. Pp. 480.

Effiong, G. S., \& Udo, I. F. (2010). Nutritive values of four indigenous wild fruits in Southeastern Nigeria. Electronic Journal of Environmental, Agricultural \& Food Chemistry, 9(7).

WHO, F. (2004). Vitamin and mineral requirements in buman nutrition. World Health Organization and Food and Agriculture Organization of the United Nations, Geneva.

World Health Organization. (2001). Evaluation of certain food additives and contaminants. In Evaluation of certain food additives and contaminants. Pp. $\mathrm{x}-107$.

Garrett, R. H., \& Grisham, C. M. (2005). Biochemistry, 3rd ed. Thomson books/Cole, Belmont, USA. Pp. 1-1086.

Gotruvalli, M. P., Chikkappaia, L., \& Shiddamalayya, N. (2016). Nutritional analysis of edible wild plants used by Hakkipikki tribes of Hassan district, Karnataka. Inter. Journal of Pharma Sciences, 8(8), 390-393.

Hanif, L., Prakash, D., \& Pal, M. (2006). Nutritional and anti-nutritional comparison of vegetable and grain Amaranthus leaves. Journal of the Science of Food and Agriculture 57(4), 573-585.

Iheanacho, K., \& Ubebani, A. C. (2009). Nutritional composition of some leafy vegetable consumed in 
Imo State, Nigeria. Jour. of Appl. Sci. and Environ. Manage, 13(2), 35-38.

Kavitha, V., \& Saradha V. R. (2013). Nutritional composition of raw fresh and dried form of spinach leaf. An international journal, 1(8), 767-770.

Krause, C., \& Mahan, L. (1984). Food, Nutrition and Diet therapy. A textbook of nutritional care $(7 \mathrm{th}$ ed). W.B. Samndere Company, London. Pp. 1-955.

Lal, H. (2008). A textbook of Biochemistry (1st ed., 2nd reprint). CBS Publishers and distributors New Delhi. Pp. 1497.

Latunde, \& Dada, G. O. (2009). Iron metabolism: Microbes, Mouse, and Man. Bio-Essays, 31(2),13091317.

Levine, M. (1995). Determination of optimal vitamin $\mathrm{C}$ requirements in humans. The American Journal of Clinical Nutrition, 62(4), 1347-1356.

Mahwash, Z. K., Sheikh, M., Farah, N., Iftikhar, I. N., \& Erum, Z. (2011). Determination of some toxic and essential trace metals in some medicinal and edible plants of Karachi city. J. Basic Appl. Sci., 7(3), 89-95.

Mohammed, M. I., \& Sharif, N. (2011). Mineral composition of some leafy vegetables consumed in Kano, Nigeria. NJBAS, 2, 208-212.

Monaci, F., Moni, F., Lanciotti, E., Gracchi, D., \& Bargagli, R. (2000). Biomonitoring of air borne metals in urban environments: new tracers of vehicle emission, in place of lead. Environ. Pollut., 107(4), 321-327.

Nisha, S., Gupta, P. C., \& Rao, C. V. (2012). Nutrient content, mineral content and antioxidant activity of Amaranthus viridis leaves. Res. J. Med. Plant, 69(3), 253-259.

Onwordi, T. C., Ogungbade, M. A., \& Wusu, A. D. (2009). The proximate and mineral composition of three leafy vegetables commonly consumed in Lagos, Nigeria. AJPAC, 3(6), 102-107.

Ötles, S., \& Ozgoz, S. (2014). Health effects of dietary fiber. Acta scientiarum polonorum Technologia alimentaria, 13(2), 191-202.

Osborne, D. R., \& Vogt, D. (1978). The analysis of nutrients in foods. Academic Press, London.

Pennmington, J. A., Schoen, S. A., Salmon, G. D., Young, B., John, R. D., \& Marts, R.W. (1995). Composition of core foods of the US food supply, 1982-1991, 1. Sodium, phosphorus and potassium. Journal of Food Composition and Analysis, 8(3), 91-128.

Radwan, M. A., \& Salama, A. K. (2006). Market basket survey for some heavy metals in Egyptian fruits and vegetables. Food and chemical toxicology, 44(8), 12731278

Saidu, A. N., \& Jideobi, N. G. (2009). The proximate and elemental analysis of some leafy vegetables grown in
Minna and Environs. Journal of Applied Sciences and Environmental Management, 13(4), 21-22.

Singh, G., Kawatra, A., \& Sehgal, S. (2001). Nutritional composition of selected green leafy vegetables, herbs and carrots. Plant Foods for Human Nutrition, 56(4), 359-364.

Sizer, F., \& Whitney, E. (2003). Nutritional concepts and controversies.

Sobukola, O. P., Dairo, O. U., Sanni, L. O., Odunewu, A. V., \& Fafiolu, B. O. (2007). Thin layer drying process of some leafy vegetables under open sun. Food Science and Technology International, 13(1), 35-40.

Tayyeb, M., Nadeem, R., Safi, U., Rahman, S., Waseem, A. Kamran, B., \& Muhammad, S. (2017). Minerals profile and proximate analysis of fresh and waste water Irrigated cabbage from Quetta Balochistan. Pure and applied Biology, b(3), 882-888.

UNICEF \& Micronutrient Initiative (1998). Major issues in the control of iron deficiency (ed. Gillespie and Stuart) Ottawa: Micronutrient Initiative, 33-35.

Uwah, E. I., Ndahi, N. P., Abdulrahman, F. I., \& Ogugbuaja, V. O. (2011). Heavy metal levels in spinach (A. caudatus) and lettuce ( $L$. sativa) grown in Maiduguri, Nigeria. Journal of Environmental Chemistry and Ecotoxicology, 3(10), 264-271.

Vasudevan, D. M., \& Sreekumari, S. (2009). Textbook of biochemical for medical students. $5^{\text {th }}$ ed, Jaypee Brothers Medical Publishers, New Delhi. Pp.1-535. 